The arthritis was monoarticular in $85 \%$ and polyarticular in $15 \%$ and was seronegative in all patients (Rheumatoïd factor and antinuclear antibodies). The synovial attack showed a wide variation in the clinical presentation, course and duration of arthritis causing diagnostic difficulties. Renal amyloïdosis occurred in 21 patients after a mean duration of FMF 10,5 years (2 to 28 years). One patient had hematuria, kidney biopsy showed mesangial IgA glomerulonephritis. Among 32 patients treated with colchicine, $80 \%$ achieved a therapeutic response.

Conclusion FMF is an inherited disease; colchicine remains the only efficient treatment to prevent both acute manifestations and amyloïdosis.

\section{AB0222 EVALUATION OF THE VISUAL ANALOGICAL SCALES (VAS) OF PAIN AND THEIR CORRELATION WITH THE OTHERS ACR ACTIVITY CRITERIA OF REHUMATOID ARTHRITIS (RA)}

C Diaz, M Cortes, C Geli, M Moreno, H Corominas, C Diaz-Torne, A Rodriguez, JM Llobet, G Vazquez. Rheumatology, Hospital de La Santa Creu I Sant Pau, Barcelona, Spain

10.1136/annrheumdis-2001.743

\section{Background}

Objectives Evaluate the VAS for global, activity, rest and nocturnal pain in relation with other activity parameters including Ritchie index.

Methods 228 outpatients with ACR-87 criteria for RA diagnostic were studied. We measure the following clinical parameters: $\mathrm{n}^{\underline{ }}$ of joints with pain and inflammation, VAS for global, activity, rest and nocturnal pain, VAS for global impression of the patient and the doctor, HAQ, morning stiffness, Ritchie index and the analytical data: ESR and CRP. The correlations among the different pain-VAS and those with other activity criteria of RA were evaluated by Pearson's correlation with the statistical packet SPSS. They are positive if $r>.5$.

Results $82 \%$ were women. Age was $60 \pm 16$. Years of evolution were $13 \pm 10.31 \%, 28 \%, 29 \%$ and $12 \%$ correspond to the functional stages I, II, III and IV respectively. $48 \%$ were seropositive. VAS-G has the highest correlations with VAS-A, R and N. there are also significant correlation among VAS-Pain and other activity parameters of RA: HAQ, Ritchie index and the global impression of the patient and the doctor. The impression of the patient correlations are higher than the doctor's.

Conclusion VAS-Pain, and specially VAS-G has a high correlation among themselves, HAQ, patient and doctor's impression and with Ritchie Index. There are no correlation among $\mathrm{n}^{\mathrm{o}}$ of articulations with pain, articulations with inflammation, CRP or ESR. The lack of the last correlation maybe related to the low inflammatory activity of the sample.

\section{AB0223 EVALUATION OF CLASSICAL NSAIDS AND COX-2 SELECTIVE INHIBITORS ON PURIFIED OVINE ENZYMES AND HUMAN WHOLE BLOOD}

${ }^{1} \mathrm{X}$ De Leval, ${ }^{1} \mathrm{JM}$ Dogne, ${ }^{1} \mathrm{~J}$ Delarge, ${ }^{2} \mathrm{JY}$ Reginster, ${ }^{2} \mathrm{Y}$ enrotin. ${ }^{1}$ Department of Medicinal Chemistry; ${ }^{2}$ Bone and Cartilage Metabolism Research Unit, Institute of Pathology, CHU Start-Tilman, Liège, Belgium

10.1136/annrheumdis-2001.744

Background
Objectives In this study, we evaluated the cyclooxygenases (COX) inhibitory profile of NSAIDs in a cellular assay using human whole blood.

Methods Human whole blood assay was performed using fresh blood from normal volunteers. COX-1 assay: Fresh blood was collected into tubes containing no anticoagulants, vortexed and incubated at $37^{\circ} \mathrm{C}$ under constant agitation for $1 \mathrm{~h}$ to allow the blood clot. The serum was then obtained by centrifugation and was assayed for thromboxane $\mathrm{B}_{2}\left(\mathrm{TXB}_{2}\right)$ using a enzyme immunoassay. COX-2 assay: Fresh blood was collected in heparinized tubes and activated by treatment with lipopolysaccharide at the final concentration of $100 \mu \mathrm{g} / \mathrm{ml}$. After $24 \mathrm{~h}$ of incubation with the drugs, plasma was collected and assayed for prostaglandin $\mathrm{E}_{2}$ $\left(\mathrm{PGE}_{2}\right)$. $\mathrm{PGE}_{2}$ production was quantified by a specific radioimmunoassay. Drugs were tested at the concentrations ranged among 0.01 to $100 \mu \mathrm{mol} / \mathrm{l}$.

Results

\begin{tabular}{llll} 
Abstract AB0223 Table 1 & & \\
\hline & COX-1 & $\begin{array}{l}\text { IC50 }(\mu \mathrm{M}) \\
\text { COX-2 }\end{array}$ & COX-1/COX-2 \\
\hline Aceclofenac & $>100$ & 0.77 & $>130$ \\
NS-398 & 8.3 & 0.34 & 24 \\
Rofecoxib & 7.8 & 0.43 & 18 \\
Nimesulide & 22 & 1.3 & 17 \\
Celecoxib & 12 & 0.77 & 16 \\
Diclofenac & 0.6 & 0.04 & 15 \\
Tenoxicam & 7.2 & 5.6 & 1.3 \\
Indomethacin & 0.07 & 0.17 & 0.4 \\
\hline
\end{tabular}

Conclusion In the whole blood test and based on the IC50 values, the majority of the NSAID tested preferentially inhibits COX-2. Aceclofenac shows the best selectivity whereas indomethacin preferentially inhibited COX-1.

\section{OP0122 TUMOUR NECROSIS FACTOR-RECEPTOR ASSOCIATED PERIODIC SYNDROME IN A FINNISH FAMILY}

${ }^{1} \mathrm{~T}$ Pettersson, ${ }^{2} \mathrm{H}$ Nevala, ${ }^{2} \mathrm{~L}$ Karenko, ${ }^{2} \mathrm{~S}$ Stjernberg, ${ }^{2} \mathrm{M}$ Raatikainen, ${ }^{2} \mathrm{H}$ Suomalainen, ${ }^{3}$ J Rauta, ${ }^{4}$ MF McDermott, ${ }^{3}$ P Peterson, ${ }^{2}$ A Ranki. 'Department of Medicine; ${ }^{2}$ Department of Dermatology, Helsinki University Central Hospital, Helsinki; ${ }^{3}$ Institute of Medical Technology, University of Tampere, Tampere, Finland; ${ }^{4}$ Medical Unit, St. Bartholomew's and the Royal London Hospital School of Medicine and Dentistry, London, UK

\subsection{6/annrheumdis-2001.745}

Background TNF receptor-associated periodic syndrome (TRAPS) is a recently defined dominantly inherited autoinflammatory syndrome, which is caused by mutations in the extracellular domains of the $55 \mathrm{kDa}$ TNF receptor, TNFRSF1A. TRAPS is characterised by periodic fevers, sterile peritonitis, pleurisy, arthritis, erysipeloid erythema of the skin, and conjunctivitis. Affected individuals have shown a shedding defect of TNFRSF1A upon stimulation and, consequently, low levels of soluble TNFRSF1A in serum.

Objectives We studied a three-generation Finnish family, where recurrent attacks of fever and abdominal pain appeared to segregate as an autosomal dominant trait.

Methods The TNFRSF1A gene was sequenced in both affected and unaffected family members. Flow cytometric analysis and 